\title{
MODIFICATIONS OF THE CURRENTLY IMPLEMENTED EUROPEAN UNION COMMON POLICY CONCERNING DIRECT PAYMENTS
}

Bartosz MICKIEWICZ, Department of Environmental Economics, Faculty of Economics, West Pomeranian University of Technology in Szczecin, Aleja Piastów 17, 70-310 Szczecin, Poland, bmickiewicz@ zut.edu.pl

The paper presents the EU trend towards simplifying of the European legislation in the Common Agricultural Policy. Author remarks the Multi-annual Financial Framework should be focused on the simplification of the CAP and points out that the law should be created in simple, transparent and understandable manner for farmers. EU Members States must respect the principles of subsidiarity, proportionality and coherence. Paying attention to direct payments, there is underlined the importance of land greening in relation to the diversification of crops and the preservation of permanent agricultural land. Author concludes that only professional farmers who have acquired payment entitlements. The review of CAP has not changed the level of funding of agricultural policy in present financial perspective.

Keywords: direct payments, review of CAP, rural areas, simplification

\section{INTRODUCTION}

The Multi-annual Financial Framework (MFF), also referred to as a financial perspective, constitutes the basis for the financial process and the budget distribution. The aim of the MFF is to provide funding for the common policy in the mediumterm as well as to maintain budget discipline and reduce expenditure growth under the CAP. The category of the financial perspective has been defined in the Treaty on the Functioning of the European Union (TFEU), and according to its interpretation it constitutes a medium-term expenditure plan of the EU, set within the applicable income limit for a period of 5 to 7 years. The transition from the initial inter-institutional agreement, which took place in 1988, to the multi-annual financial framework was supposed to ensure that expenditure was systematized and kept within the limits of its own resources. Therefore, the Multiannual Financial Framework should not be treated as merely a simple plan of revenue-and-expenditure breakdown by year. Indeed, the MFF provides a set of legal acts referring to the whole of the EU public finances over a long period of time, i.e. expenditure, revenue, financial discipline, more efficient budget implementation and the management principles of the EU budget (Future Financing, 2005).

Legal acts passed in the form of regulations by the European Parliament, the European Council and the Commission in financial terms - aimed at creating the Community's own resources, extending parliamentary budgetary powers, creating a European monetary system or creating a large internal market. In this sense, a financial perspective, including the budget, constitutes the most important financial plan of the European Union. At present, the Multi-annual Financial Framework is created by the Parliament, the Council and the European Commission (Proposal for a Council Regulation, 2010).

Thus, under the Treaty of Lisbon, the multi-annual financial framework has changed from an inter-institutional agreement into a legally binding act, which is subject to further amendments and restructuring (Draft Inter-institutional Agreement 2017).

\section{THE ISSUES, PURPOSE AND SCOPE OF THE RESEARCH}

In the second half of 2016, the European Commission launched a mid-term review of the multi-annual EU budget for 2014-2020. The purpose of the review was to concentrate the EU budget on meeting the EU's main needs, such as economic development, creating new jobs and resolving the migration crisis.

The simplification of the Common Agricultural Policy is the part of the overall EU strategy for improving legislation. Within the review, the EU wants to simplify and reduce regulations, thereby reducing bureaucracy and regulatory burdens for businesses, citizens and public administration. The simplification of the Common Agricultural Policy should take place on specified terms. It is important to maintain the policy objectives and key elements of the reformed the CAP and to ensure the stability of the law for farmers so that the simplification will not result in the restricted access to CAP support. The need to focus on the areas where both the entities implementing the CAP and the beneficiaries of this policy would benefit most from the reduction of administrative burdens is another objective of the simplification. Another objective is to increase the clarity of

Copyright (C) 2017 The Authors. Published by Aleksandras Stulginskis University. This is an open-access article distributed under the terms of the Creative Commons Attribution License (CC-BY 4.0), which permits unrestricted use, distribution, and reproduction in any medium, provided the original author and source are credited. 
legislation and its consistency, especially between Pillar I and Pillar II of the CAP, in order to achieve a synergy effects (Draft Conclusions of the Council... 2015).

The paper presents mid-term evaluation proposals referring to the issues related to direct payments. The simplification proposals have been shown against the background of the solutions implemented so far under the CAP and defined for $2014-$ 2020. The paper presents a review of relevant concepts and confirms the opinions of other authors involved in European Union Common Policy modifications and restructuring. The paper uses the methods of synthesis, analysis, deduction, and induction. Based on data gathered from the literature, the author performed an inference, i.e. clearly summarised the most important results of the analysed studies. The author conducted the study in 2017 mainly based on the EP, the European Commission and the European Council documents.

\section{RESULTS AND DISCUSIONS}

\section{The multi-annual financial framework function periods}

Since 1988, the European Union has adopted the multi-annual financial framework five times: the Delors I package from 1988 to 1992, the Delors II package from 1993 to 1999, Agenda 2000 from 2000 to 2006, "Building Our Common Future" from 2007 to 2013 and "Investing Today for Tomorrow's Europe" from 2014 to 2020.

Under the financial perspective, the Common Agricultural Policy has always been an important item. Following the restructuring of the CAP and the introduction of direct payments (1992), expenditure on the Common Agricultural Policy has shown a downward trend from $62 \%$ to $52 \%$ of the total EU budget. Despite the fact that 2004 was the beginning of the new Member States accession (2004 NEU-10 and 2007 NEU-2), the decline in CAP support measures have not been halted - they accounted for 52\% of the total budget in 2009 and $45.8 \%$ - in 2010. In the current financial perspective, CAP expenditure accounts for about $36 \%$ of the total EU budget commitments. In parallel with the decline in the percentage share of the CAP budget under the MFF, there has been a shift between the pillars of the Common Agricultural Policy, in favor of Pillar I of the $\mathrm{CAP}$, with which the increasing area payments and agricultural markets are generally associated. This is happening at the expense of rural development (Pillar II of the CAP).

The first CAP budget of all eligible Member States (2007 - 2013) was $€ 374.5$ billion, of which $€ 286.2$ billion (76.5\%) was allocated to Pillar I of the CAP and $€ 88.3$ billion (23.5\%) - to Pillar II of the CAP.

The next CAP budget for 2014 - 2020 was set at $€ 408.3$ billion, of which $€ 308.7$ billion (75.6\%) were allocated to direct payments (Pillar I of the CAP) and $€ 99.6$ billion (24.4\%) for the rural development program ( Pillar II of the CAP) (Czyżewski et al., 2014).

\section{Simplification principles of the Common Agricultural Policy}

The European Commission has sought for the simplification of the Common Agricultural Policy since the very beginning of the European Community. That is why procedures have been developed and recommendations have been made. The exemption of farmers and agricultural administration from the excessive requirements and burdens that have arisen in the course of CAP implementation has become the underlying principle of the simplification. It has also been assumed that the simplification should not reduce the competitiveness of the agricultural sector or cause job loss but it should substantially contribute to the development of rural areas. The simplification should be consistent with the overall objectives of environmental policy, food safety policy, cohesion policy and the protection of the EU's financial interests.

In 2009 the European Commission took a number of both technical and political measures to implement the simplification. The first steps comprised recognition and elimination of outdated legislation. The technical simplification included a review of the regulatory framework, administrative procedures and management mechanisms to improve and increase their efficiency. On the other hand, political simplification was based on removing excessively complex bureaucratic obstacles by improving support for agriculture and simplifying rural development instruments (Communication from the Commission to the EP and the Council, 2016).

The most important simplification elements proposed as a result of the CAP functioning assessment include further decoupling of the payments from production as well as the withdrawal of a number of programs such as payments for energy crops and durum wheat or programs of removal from the market for cream, butter and concentrated butter. As indicated by the analyses (Czyżewski et al., 2014), the support dependent on production entails an additional administrative burden on farmers. Further decoupling of the payments from production will automatically lead to a reduction in this burden. The simplifications also allow modification of the rules for the minimum level of modulation as well as provisions on the national reserve and the payment entitlements resulting from it.

\section{The simplification of the cap in the scope of direct payments}

Direct payments constitute one of the main instruments for the implementation of the Common Agricultural Policy and they are responsible for supporting and stabilizing agricultural incomes, for reducing production costs and for maintaining production in the areas of adverse farming conditions. The area payment system is not uniform across the European Union. In the EU-15 countries the system is still based on solutions that are calculated on the basis of historically established reference yields (SPS), whereas for the new Member States (NEU-12), the Single Area Payment Scheme (SAPS) was still maintained.

The basic rule is that payments are granted to active farmers on the basis of entirely new entitlements the number of which depends on the number of hectares declared. The payment system is applied in accordance with the principle of crosscompliance, which involving the observance of specified rules of environment protection, animal welfare and other healthrelated activities (hygiene, veterinary). There is also the trend to reduce differences in payment levels between farmers and regions. The SAPS countries were allowed to increase the payment level per uniform area payment by the maximum of $3 \%$, 
which is to enable more effective use of funds. The principles of direct payments are intended to make better use of the synergy effect with Pillar II (EP / Council Regulation 1305, 2013).

The basic payment for new young farmers (under the age of 40) was increased by additional $25 \%$ for the first five years of their activity. The payment applies to young farmers holding no more than 25 hectares. The novelty lies in providing support for small farmers to increase their vitality, to improve their competitiveness and to reduce bureaucracy. Within the framework of the multi-annual budget review, the Commission put forward several legislative proposals aimed at improving EU funding (EP and Council Regulation, 2013).

The priorities identified by the EU with respect to the need for the direct payments system simplification include the requirements for greening, in particular the application of the rules on permanent pasture or the crop diversification period, ecological focus areas (EFA) and the requirements for equivalent practices. The direct payment system enables farmers to apply electronically for both direct payments and the payments connected with adverse condition areas.

The distribution of direct payments, i.e. the basic income support which provides farmers with compensation for the provision of public goods and services, is gradually shifting to the distribution of support between Member States and regions so that the largest differences in the level of payments received by farmers in different parts of the EU are eliminated (EP Regulation and Council No. 1307, 2013).

The general direction of action comes down to reducing the level of expenditure related to direct payments. The direct payments for large farms have been reduced by $5 \%$ or more if the annual payment exceeds $€ 150,000$. In this way, Member States will be able to use the saved money for rural development. At present, the differences in payment levels between Member States have been partially leveled. In the countries where the average direct payment per hectare is $90 \%$ of the EU average, the level of payments will be gradually increased. It has been assumed that in 2019 the minimum level across the EU should be around $€ 196$ per hectare. Leveling of the differences will be financed by the EU15, where the average direct payment is higher than the EU average. The direct payments for new and young farmers (below the age of 40) will be increased for the first 5 years of their activity. Moreover, other support measures under the Rural Development Program will be available to them. The farmers who receive little direct payments will be able to use a simplified aid scheme for small farms in the near future. As for the types of formalities, the system will be easier for both small farmers and national administrations. As for greening, it has been decided that $30 \%$ of direct payments would be reserved for farmers who observe climate and environmental criteria. The simplification with respect to greening will allow Member States to adopt a more flexible approach to the implementation of this mechanism. In addition, the mechanism aims at avoiding multiple audits of these requirements, proposing a proportionate reduction in administrative penalties, especially for minor infringements. It seems that greening will be of greater importance in the next financial perspective (after 2020) due to climate change to which agricultural production contributes significantly. On the other hand, organic production will automatically be considered a factor that meets the greening criteria. New regulations state that the property owners who do not run real agricultural business or the companies which own vast grasslands (e.g. airports) will not be able to apply for direct payments. Member States will be able to manage their financial envelopes more flexibly. Each state will be allowed to move up to $15 \%$ of its pool of funds between the two pillars of the CAP, whereas a country whose pool of funds designated to direct payments is lower than the EU average will be able to shift up to $25 \%$ of funds from Pillar II to Pillar I (EP / Council Regulation 1307, 2013).

The Land Parcel Identification System (LPIS), which facilitates the submission of payment applications based on digital ortophotomaps, is extremely helpful for the farmers who benefit from area payments. Ortophotomaps play a crucial role in the implementation of the agricultural payment system, since they are used as the primary element of the Land Parcel Identification System to define functional surfaces for which the farmer actually receives the payment; moreover, the LPIS constitutes the basis for verifying the submitted applications for payments (Litwiniuk, 2015).

\section{FINAL REMARKS}

The simplification of the Common Agricultural Policy is the part of the overall EU strategy for improving legislation. The EU aims at substantial reduction and simplification of the regulations wherever it is possible, thereby reducing bureaucracy and regulatory burdens for businesses, citizens and public administration. CAP simplification is essential for farms to be more competitive as well as to maintain and create jobs and to contribute to the proper development of rural areas.

The mid-term review of the MFF does not anticipate for changes to the level of CAP funding in the current financial perspective. However, the EU budget requires a revision due to the occurrence of the new phenomena connected with the migration crisis, the influx of refugees, external security and Brexit. The UK contribution will not be paid in 2020, which will adversely affect payments under the CAP.

Taking into account the downward trends in the CAP budget, the percentage decline of the share in the multi-annual financial framework should be expected in the next financial perspective. In view of the aspirations of Central and Eastern European countries seeking to level the area payment, the importance of Pillar I of the CAP (up to 80-85\%) should be expected at the expense of the decline in the importance of rural development programs. The direct payments leveling process will only take place within the framework of a new redistribution of financial instruments. The importance of support measures for greening, in the context of the sustainable use of grassland, will increase as will the importance of crop diversification and the definition of the types of pro-ecological areas (EFA). Programs for greening and "ecologization" of agriculture and rural areas are closely linked to the rapid pace of global climate change. 


\section{REFERENCES}

1. Draft Interinstitutional Agreement between the European Parliament, the Council and the Commission on cooperation in budgetary matters, Brussels, 2010, COM (2010) 73 final.

2. Future Financing of the European Union, 2005, Report with evidence; House of Lords, European Union Committee.

3. Litwiniuk, P, 2015, Uproszczenia Wspólnej Polityki Rolnej - nośny slogan czy absolutna konieczność, I edition, Studia Iuridica Agraria, Białystok. [In Polish]

4. The communication from the Commission to the EP and the Council, 2016, Mid-term review of the Multiannual Financial Framework 2014-2020 EU-led performance budget, Brussels

5. Proposal for a Council Regulation laying down the multi-annual financial framework for the years 2007-2013, 2010, Brussels, COM (2010) 72 final, 2010/0048 (APP).

6. Draft Council Conclusions on Simplification of the Common Agricultural Policy, 2015, EU Council, Brussels.

7. EP and Council (EU) Regulation No. 1307/2013 of 17 December 2013 laying down rules for direct payments to farmers under support schemes under the Common Agricultural Policy.

8. EP and Council (EU) Regulation No 1305/2013 of 17 December 2013 on support for rural development by the European Agricultural Fund for Rural Development (EAFRD) and repealing Council Regulation (EC) No 1698/2005.

9. Czyżewski, A., Grochowska, R., Kułyk, P. 2014. Rola determinant makroekonomicznych i instytucjonalnych w kształtowaniu strategii rozwojowych rolnictwa. Analiza uwarunkowań i wyzwań rozwoju sektora rolno-żywnościowego w Polsce na tle tendencji światowych, I edition, Instytut Ekonomiki Rolnictwa i Gospodarki Żywnościowej - Państwowy Instytutu Badawczego, Warszawa. [In Polish] 